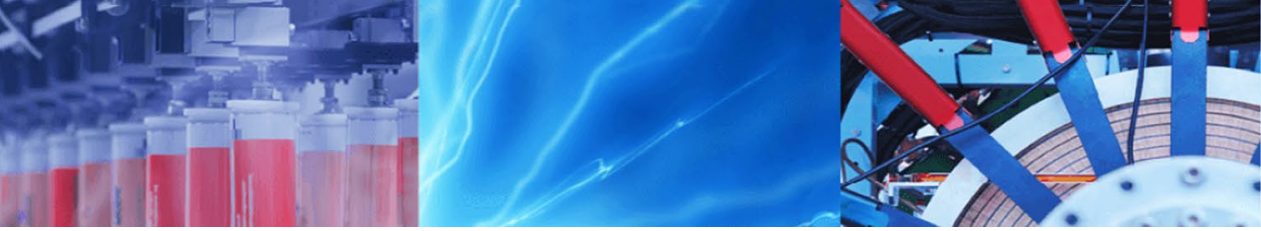

Research Article

\title{
Detection of biogenic magnetic nanoparticles in ethmoid bones of migratory and non-migratory fishes
}

\author{
Svitlana Gorobets ${ }^{1} \cdot$ Oksana Gorobets $^{1,2} \cdot$ Maryna Bulaievska $^{1}$ (I) Iryna Sharay ${ }^{1,2}$
}

(c) Springer Nature Switzerland AG 2018

\begin{abstract}
In this paper, the presence of biogenic magnetic nanoparticles, their localization, and quantity in the ethmoid bone and lateral ethmoid bone of Atlantic salmon, Salmo salar, northern pike, Esox lucius, and silver carp, Hypophthalmichthys molitrix, were studied using atomic force microscopy and magnetic force microscopy. It is shown that biogenic magnetic nanoparticles, grouped mainly in short or long chains, are contained in the ethmoid and lateral ethmoid bones of migratory (Atlantic salmon, Salmo salar) and non-migratory (northern pike, Esox lucius, and silver carp, Hypophthalmichthys molitrix) fishes. The number of biogenic magnetic nanoparticles in the ethmoid and lateral ethmoid bones of non-migratory fishes is of the same order of magnitude as in migratory fishes. The localization of biogenic magnetic nanoparticles in the ethmoid and lateral ethmoid bones of migratory and non-migratory fishes is similar. Thus, for the first time it was shown that the presence of biogenic magnetic nanoparticles in the ethmoid and lateral ethmoid bones of fishes is not related to their ability to navigate in the geomagnetic field.
\end{abstract}

Keywords Biogenic magnetic nanoparticles $\cdot$ BMN biomineralization proteins $\cdot$ Migratory fishes $\cdot$ Non-migratory fishes . Ethmoid bone $\cdot$ Magnetic force microscopy

\section{Introduction}

At the present time, biogenic magnetic nanoparticles (BMNs) have been found experimentally in algae and protists [1], worms [2], chitons [3], snails [4], ants, butterflies [5-7], honey bees [7, 8], termites [9], lobsters [10], newts [11], migratory and non-migratory fishes [12-15], sea turtles [16, 17], birds [18-21], bats [22], dolphins and whales [23], pigs [24], and humans [13, 25-29]. BMNs have been found in various human organs and tissues in normal condition $[13,25-27,29]$.

The main idea of the presence of BMNs in organs and tissues of living organisms was associated with magnetotaxis and magnetoreception; therefore, organisms that move to fairly large distances in space were studied. In this connection, the question arises as to whether there is a similar localization of BMNs (the formation of chains) and how much their quantity differs in the organs and tissues of animals that hypothetically can be responsible for the magnetoreception (beak of birds, ethmoid bone of migratory fishes, brain), and other organs (heart, liver, lungs, intestines, muscles, skin, etc.), as well as in various organs of non-migratory organisms. This question is very important for understanding whether BMNs have a general function unrelated to magnetotaxis and magnetoreception. This is especially important in connection with the theoretical prediction of a common BMN biomineralization mechanism for all living organisms by bioinformatic methods [30].

That is why the purpose of this work is to determine the presence of BMNs in the ethmoid and lateral ethmoid bones of non-migratory fishes. The study of the localization and number of BMNs in non-migratory fishes and their comparison with migratory fishes have shown that

$\triangle$ Maryna Bulaievska, bulaievska.mo@ukr.net|'Department of Bioinformatics, Igor Sikorsky Kyiv Polytechnic Institute, Kiev 03056, Ukraine. ${ }^{2}$ Institute of Magnetism NAS of Ukraine and MESYS of Ukraine, Kiev 03142, Ukraine.

SN Applied Sciences (2019) 1:63 | https://doi.org/10.1007/s42452-018-0072-1 
the BMNs in the ethmoid and lateral ethmoid bones of fishes do not participate in the orientation of animals in the external magnetic field of the Earth.

\section{Material and equipment}

The proteome of migratory (Atlantic salmon, Salmo salar) and non-migratory (northern pike, Esox lucius, and silver carp, Hypophthalmichthys molitrix) fishes was aligned with the proteome of the magnetotactic bacteria (MTB) Magnetospirillum gryphiswaldense MSR-1, the BMN biomineralization mechanism in which has been studied in detail [31, 32], using the methods of comparative genomics. Pairwise and multiple alignment methods of the BLAST program of the National Center for Biotechnology Information were used to assess the degree of similarity between BMN biomineralization proteins of Magnetospirillum gryphiswaldense MSR-1 and proteins of migratory and non-migratory fishes. The generally accepted criteria were taken into account for the estimation of the degree of similarity of aligned sequences: the Ident (the number of identical amino acid residues of proteins), the E-value (the number reflecting the statistical significance of the alignment), the length (the length of the alignment), and the functions of the proteins being studied [33].

Determination of the presence of BMNs and the study of their localization in the ethmoid and lateral ethmoid bones of Atlantic salmon, Salmo salar, northern pike, Esox lucius, and silver carp, Hypophthalmichthys molitrix, was carried out using the "Solver PRO-M» scanning probe microscope by atomic force microscopy (AFM) and magnetic force microscopy (MFM).

The magnetic probe MFM_LM series with chip size $3.4 \times 1.6 \times 0.3 \mathrm{~mm}$, coated by $\mathrm{CoCr}$, was used. This probe was used for both AFM and MFM imaging. The non-contact AFM (NC-AFM) mode was applied. The MFM scanning was carried out at a constant distance from the sample surface after AFM scanning. The probe "lift" height was $100 \mathrm{~nm}$. The cantilever was calibrated using the test samples. Calibration of the probe was carried out immediately before the measurements.

The bone material of fishes was prepared before AFM and MFM scanning. Fixation of bone tissue was carried out in a $10 \%$ formalin solution. The duration of fixation was $24 \mathrm{~h}$. After that, the bone tissue washed in distilled water and conducted through ethanol with increasing concentration (from 50 to 100\%). Decalcification of bone tissue was carried out after complete fixation in a $10 \%$ formalin solution. A 5\% nitric acid solution was used for decalcification of bone tissue, and the duration of decalcification was $24 \mathrm{~h}$. After decalcification, the samples of the ethmoid and lateral ethmoid bones were rinsed for $24 \mathrm{~h}$ in $70 \%$ ethanol. The next stage was the impregnation of the decalcified bones with liquid paraffin at a temperature of $55^{\circ} \mathrm{C}$. After the solidification of paraffin at room temperature, a paraffin block was obtained. Slices from a paraffin block $5 \mu \mathrm{m}$ thick were obtained using a microtome. After receiving the slices, they were placed on slides. The last stage was the release of slices from the mounting medium.

\section{Results and discussion}

In work [24], the presence of BMNs was theoretically shown in the overwhelming majority of organs and tissues of human using bioinformatic analysis. In turn, an analysis of the experimental data showed that BMNs are present in relevant or analogous fish organs and tissues (Table 1).

BMNs have been found experimentally in vital organs such as the brain [13, 25, 34, 35], heart [29, 36], liver [29, $36]$, as well as in human [37] and fish [12, 15, 38] ethmoid bone. The presence of BMNs in human lungs, intestines, muscle tissue, and skin was theoretically predicted [24],
Table 1 BMNs presence in different human and fish organs and tissues

\begin{tabular}{lll}
\hline $\begin{array}{l}\text { Human organs with theoreti- } \\
\text { cally predicted BMN presence } \\
(+)\end{array}$ & $\begin{array}{l}\text { Experimentally confirmed } \\
\text { BMN presence in human } \\
\text { organs }\end{array}$ & $\begin{array}{l}\text { Experimentally confirmed BMN pres- } \\
\text { ence in relevant or analogous fish } \\
\text { organs }\end{array}$ \\
\hline Brain (+) & $\begin{array}{l}\text { Brain [13, 25, 35] } \\
\text { Heart [29] }\end{array}$ & $\begin{array}{l}\text { Brain [13] } \\
\text { Heart [36] }\end{array}$ \\
Heart (+) & Liver [29] & Liver [36] \\
Liver (+) & Ethmoid bone [37] & Ethmoid bone \\
Ethmoid bone (+) & & {$[12,15,38]$} \\
Lungs (+) & & Gills [36] \\
Intestines $(+)$ & & Intestines [36] \\
Muscle tissue $(+)$ & & Muscle [38, 40] \\
Skin (+) & Skin [38-40] \\
Eye $(-)$ & & Eye [36, 40] \\
\hline
\end{tabular}


and the presence of BMNs in relevant or analogous fish organs was experimentally confirmed $[36,38-40]$. The analysis of the experimental data about the presence of BMNs in various organs and tissues of animals completely confirms the results of the bioinformatic analysis.

Most of the proteins that are involved in the BMN biomineralization in MTB are encoded in the magnetosome island (MAI) (in MamGFDC, Mms, and MamAB operons) [31] and are a manifestation of the genes of the magnetosome island [32, 41]. The MamA, MamB, MamM, MamE and MamO are proteins, without which the process of biomineralization of BMNs in MTB is impossible $[42,43]$. Other proteins of the MTB MAI belong to regulatory proteins that are responsible for the control of shape, size, amount of BMNs in the cell, the formation of magnetosomal vesicles, and the formation of chains of BMNs [42]. MamK protein is a regulatory protein and is responsible for the formation of actin filaments and ensures the formation of chains of BMNs in cells of living organisms [44].

The homology of the MAI proteins of Magnetospirillum gryphiswaldense MSR-1 and proteins of migratory and nonmigratory fishes was confirmed using generally accepted criteria. When comparing the MTB proteins and proteins of Atlantic salmon and northern pike, the Ident value is more than 18\% [15], which indicates homology of MTB proteins and fish proteins [33]. Today, the recommended E-value threshold for searching for protein homologs in the NCBI database should be $<0.05$, which ranges from $1 \mathrm{e}-29$ to 0.023 when aligning proteins of Magnetospirillum gryphiswaldense MSR-1 and proteins of migratory and non-migratory fishes [15]. The length of the alignment should be $>100$ amino acid residues. When comparing MTB proteins and proteins of the Atlantic salmon (Salmo salar), the length is 59-177 amino acid residues, and when comparing MTB proteins and northern pike (Esox lucius) proteins, the length is 101-174 amino acid residues [15]. A comparison of the functions of MTB proteins and proteins of Atlantic salmon and northern pike is necessary only for additional confirmation of protein homology.

The study of the MAI proteins of Magnetospirillum gryphiswaldense MSR-1 and proteins of migratory and non-migratory fishes showed that the corresponding homology proteins belong to the same families of proteins (Table 2).

An important step in bioinformatic analysis is the comparison of the functions of BMN biomineralization proteins of Magnetospirillum gryphiswaldense MSR-1 and homology proteins of Atlantic salmon and northern pike (Table 3).

Table 2 Homologs of MAl proteins of Magnetospirillum gryphiswaldense MSR-1 among proteins of Atlantic salmon and northern pike

\begin{tabular}{|c|c|c|c|c|c|c|}
\hline \multirow{3}{*}{$\begin{array}{l}\text { Migratory and non-migratory } \\
\text { fishes }\end{array}$} & \multicolumn{6}{|c|}{ Magnetospirillum gryphiswaldense MSR-1 proteins } \\
\hline & MamA & MamB & MamM & MamO & MamE & MamK \\
\hline & \multicolumn{6}{|c|}{ Migratory and non-migratory fish proteins } \\
\hline Atlantic salmon, Salmo salar & TPR & Zinc transporter 4 & Zinc transporter 9 & Serine protease HTRA1 & Serine protease HTRA1 & Actin \\
\hline Northern pike, Esox lucius & $\begin{array}{l}\text { PEX5- } \\
\text { related } \\
\text { protein }\end{array}$ & Zinc transporter 4 & Zinc transporter 9 & Serine protease HTRA1 & Serine protease HTRA1 & Actin \\
\hline
\end{tabular}

Table 3 Comparison of known functions of the Magnetospirillum gryphiswaldense MSR-1 proteins and the Atlantic salmon and northern pike homology proteins

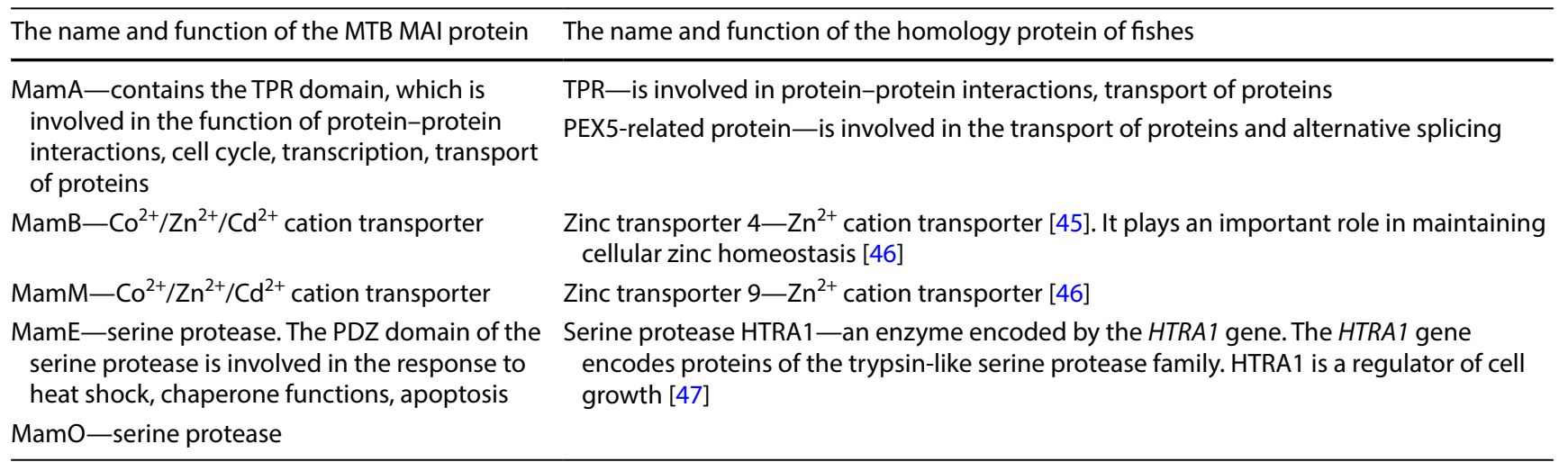


The functions of MamA, MamB, MamM, and MamE proteins are the same as the functions of migratory and non-migratory fish proteins that confirms their homology, established by bioinformatic analysis. At the same time, the presence of homologs of the MamK protein in all studied organisms suggests the possible formation of chains of BMNs by these organisms, which is confirmed by the results of MFM, which are given below. In addition, the presence of homologs of the MamK protein in all studied organisms may indicate the association of BMNs of these organisms with the cell membrane.

The multiple alignment of Mam proteins of MTB (the ability to BMN biomineralization was proved experimentally), the homologous proteins of migratory fish Atlantic salmon (the ability to BMN biomineralization was experimentally proved) and the homologous proteins of non-migratory fish northern pike was done. A search for conservative motifs that are responsible for the BMN biomineralization ability was made, and it was shown that such motifs of northern pike proteins are almost preserved compared to Atlantic salmon proteins.

Since homologs of Mam proteins were found in fishes and other multicellular organisms, and the ability to BMN biomineralization by these organisms has been experimentally proved by various methods $[12,13,23$, $28,36,38-40]$, it is unlikely that there are two analogous, but not homologous, mechanisms for the synthesis of magnetic nanoparticles in nature.

The AFM images make it possible to investigate the surface of the slices of the ethmoid and lateral ethmoid bones of the Atlantic salmon, Salmo salar, northern pike, Esox lucius, and silver carp, Hypophthalmichthys molitrix. In turn, the MFM images reflect the spatial distribution of BMNs, which are represented by black and white dots on the MFM images of the samples under study. The results of the study of the slices of the ethmoid bone of Atlantic salmon, Salmo salar, northern pike, Esox lucius, and silver carp, Hypophthalmichthys molitrix, are shown in Fig. 1, and the results of the study of lateral ethmoid bone of Atlantic salmon, Salmo salar, northern pike, Esox lucius, and silver carp, Hypophthalmichthys molitrix, are given in Fig. 2.

To increase the resolution of the images, an AFM and MFM study of the $15 \times 15 \mu \mathrm{m}$ section of Atlantic salmon ethmoid bone and the $10 \times 10 \mu \mathrm{m}$ section of northern pike ethmoid bone was carried out (Fig. 3).

The dark "spikes" (Figs. 1, 2) are obtained only as a result of MFM scanning and do not arise at AFM scanning of the sample surface topography. The repeating of MFM scanning several times in different (perpendicular) directions of scanning does not change the spatial distribution of "spikes." It proves that the "spikes" characterize the presence of magnetic nanoparticles. Figures $1 c$, $f$, $i$ and $2 c$, $f$, $i$ represent the overlapping of AFM topography image with MFM image. It means that MFM and AFM images were combined to one image with the purpose of revealing peculiarities of topography of the surface in the vicinity of BMNs.

As can be seen from Figs. $1 \mathrm{~b}, \mathrm{e}, \mathrm{h}$ and $3 \mathrm{~b}, \mathrm{~d}$ in the ethmoid bone of both migratory fish, Atlantic salmon, Salmo salar, and non-migratory fishes, northern pike, Esox lucius, and silver carp, Hypophthalmichthys molitrix, BMNs are mainly associated in short or long chains. It can be seen from Fig. $2 b, e, h$ that the BMNs in the lateral ethmoid bone of the fishes under study are also mainly assembled into chains.

BMNs are found near the cavities through which nerve fibers and blood vessels pass in the human ethmoid bone [37]. So the BMNs were found mainly near the cavities through which the olfactory nerve fibers and small vessels pass from the nasal cavity of the skull in the ethmoid bone of fishes.

Table 4 gives data on the quantity of BMNs in the ethmoid and lateral ethmoid bones of migratory and nonmigratory fishes.

The number of BMNs in the ethmoid and lateral ethmoid bones of non-migratory fishes (northern pike and silver carp) is of the same order of magnitude as in migratory fish (Atlantic salmon).

\section{Conclusions}

In this paper, it is shown that the proteins responsible for the biomineralization of BMNs in migratory (Atlantic salmon, Salmo salar) and non-migratory (northern pike, Esox lucius) fishes have the same functions confirming their homology, established by bioinformatic analysis.

The results obtained using MFM show that the ethmoid and lateral ethmoid bones of Atlantic salmon, Salmo salar, northern pike, Esox lucius, and silver carp, Hypophthalmichthys molitrix contain mainly short and long chains of BMNs. The localization of BMNs in the ethmoid and lateral ethmoid bones of migratory and non-migratory fish does not differ. BMNs are located mainly near the cavities through which the fibers of the olfactory nerves and small vessels pass. The number of BMNs in the ethmoid and lateral ethmoid bones of migratory and non-migratory fishes is of the same order of magnitude.

Bioinformatic analysis, as well as our experimental data and data of works of other authors, allows us to state that BMNs in the ethmoid and lateral ethmoid bones of migratory and non-migratory fishes are not related to their ability to migrate in the Earth's magnetic field. This statement contradicts the formulation of the 


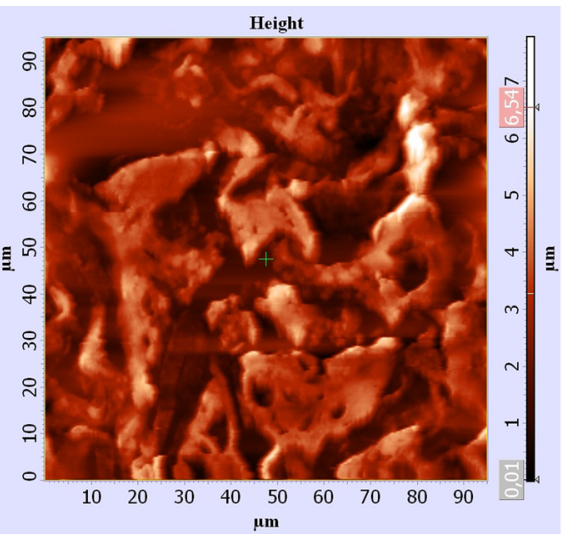

(a)

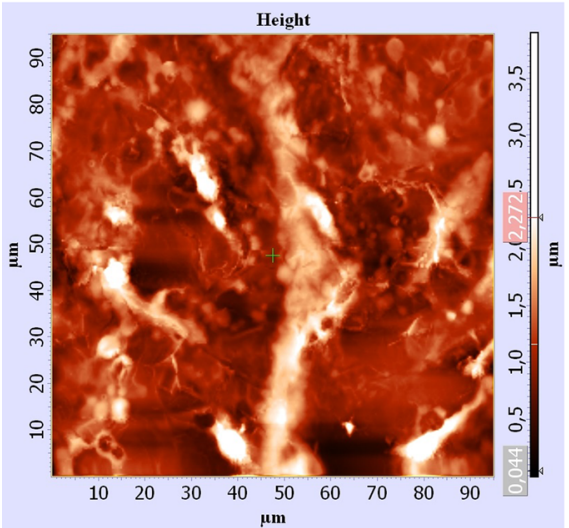

(d)

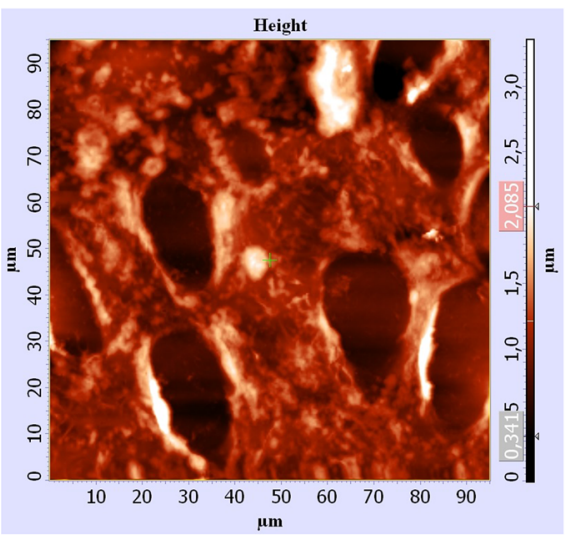

(g)

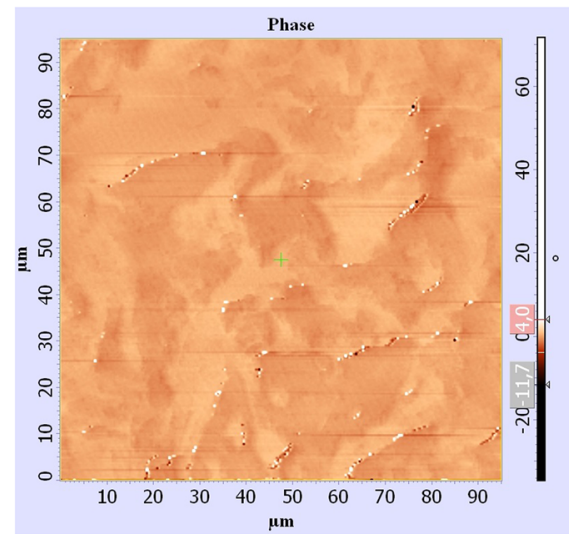

(b)

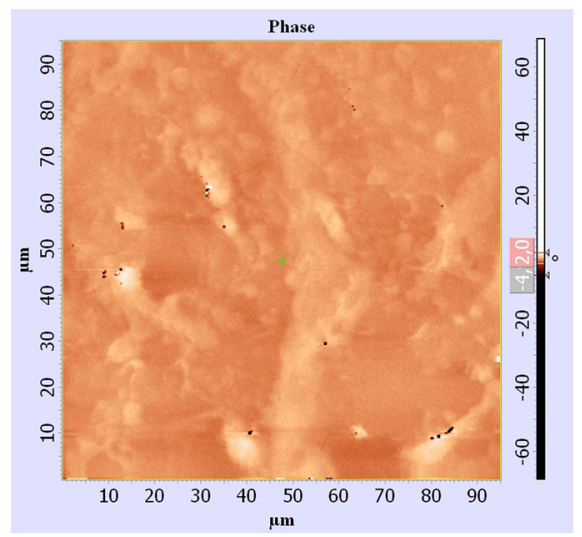

(e)

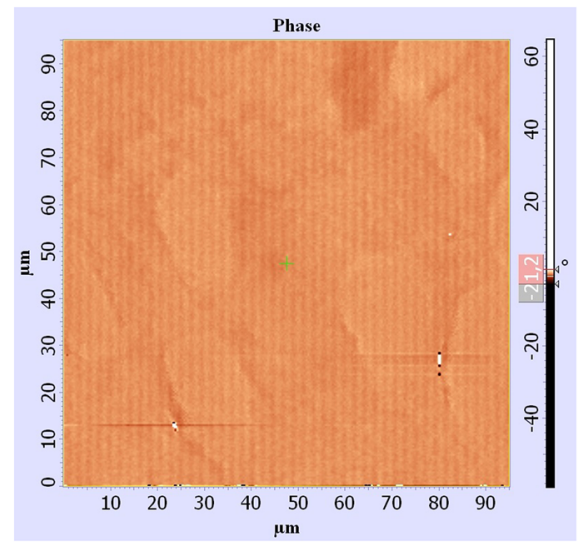

(h)

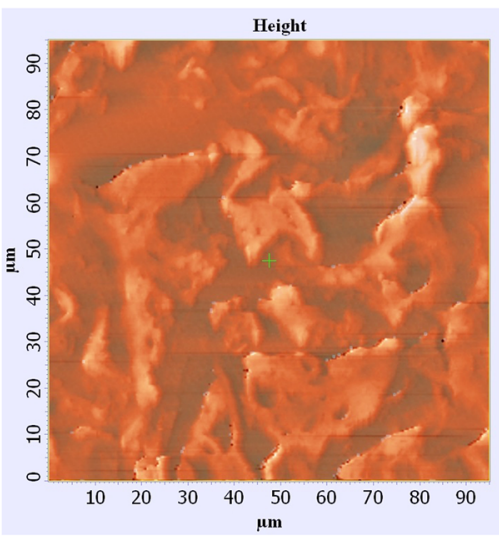

(c)

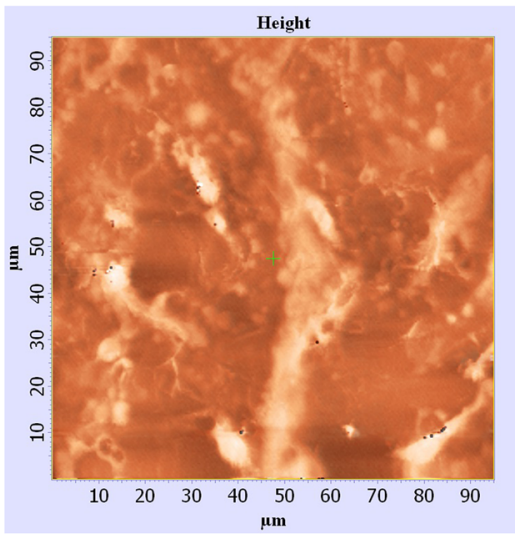

(f)

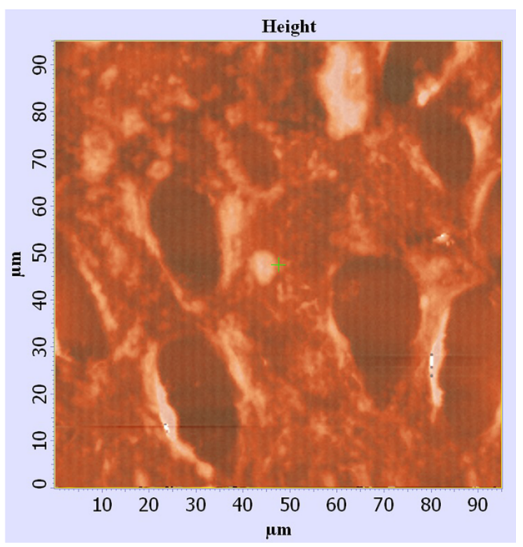

(i)
Fig. 1 Images of Atlantic salmon ethmoid bone: a AFM image, $\mathbf{b}$ MFM image, c combined AFM and MFM images; images of northern pike ethmoid bone: $\mathbf{d}$ AFM image, e MFM image, $\mathbf{f}$ combined

magnetite-based hypothesis for magnetoreception. However, a number of other studies are not consistent with the hypothesis that the main function of BMNs is magnetoreception, for example, detection of BMNs in human and mammalian organs, not related to migration: heart, liver, spleen [29], adrenal glands, kidneys
AFM and MFM images; images of silver carp ethmoid bone: $\mathbf{g}$ AFM image, $\mathbf{h}$ MFM image, $\mathbf{i}$ combined AFM and MFM images

and lungs [24], as well as the detection of BMNs in other non-migratory organisms and non-magnetotactic bacteria [48]. The work [49] showed that the destruction of the nerves connecting magnetite in the bird's beak with the brain does not affect the ability of the birds to migrate. Our study and the above studies are useful, as 


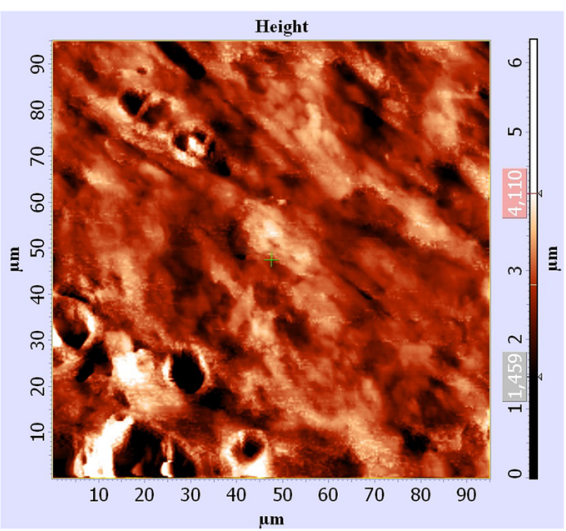

(a)

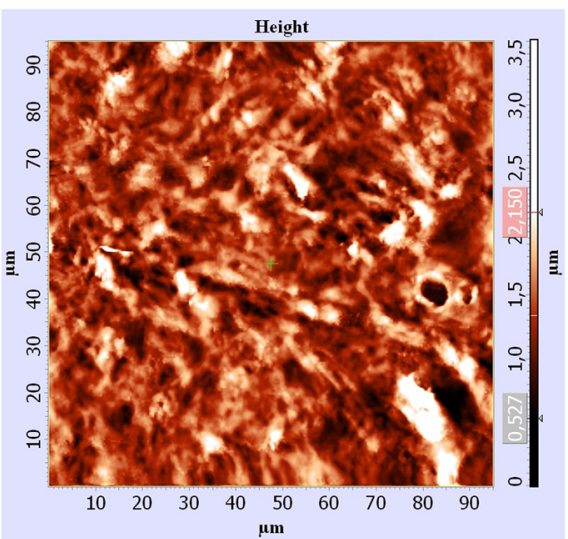

(d)

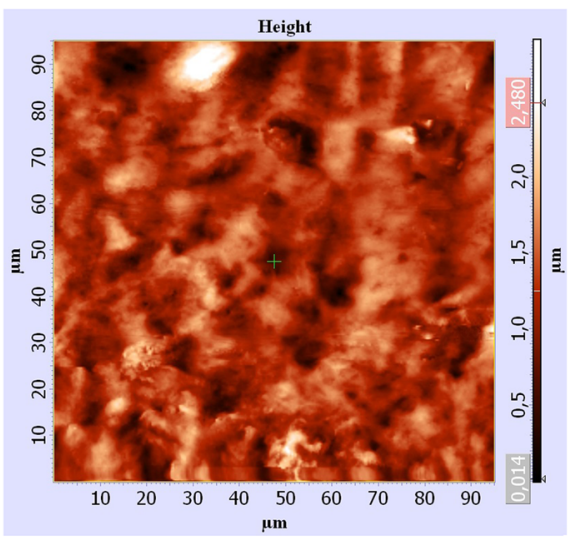

(g)

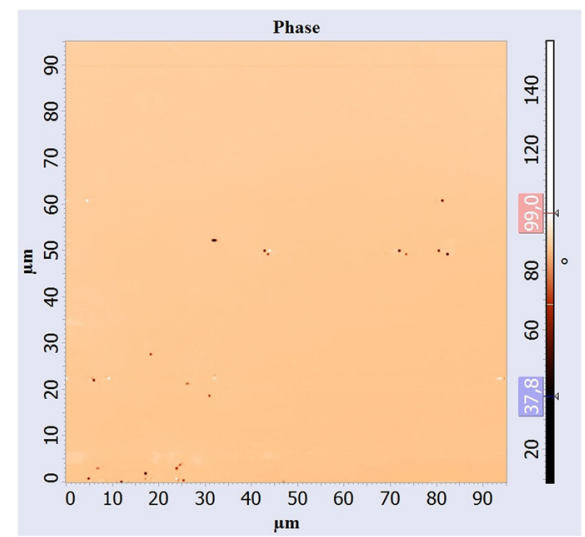

(b)

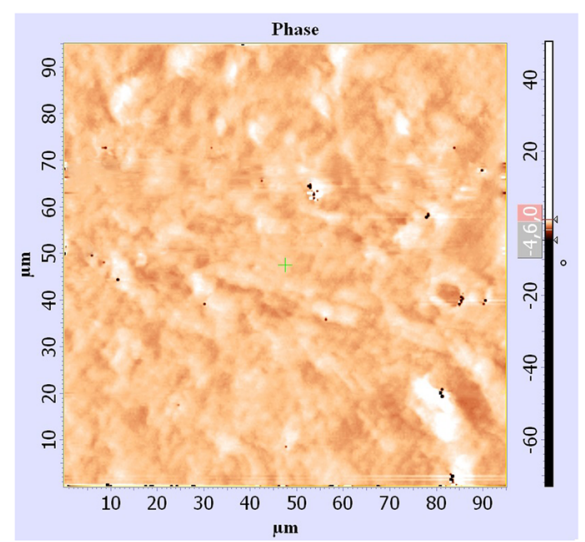

(e)

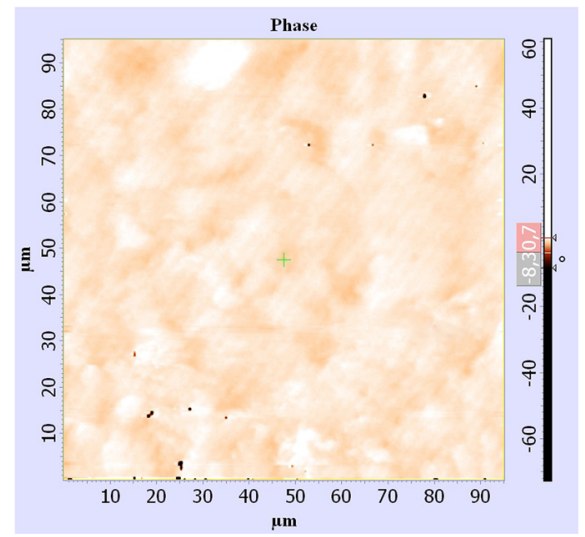

(h)

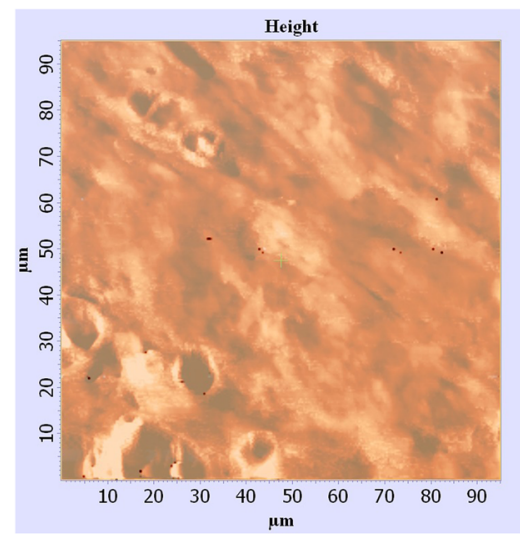

(c)

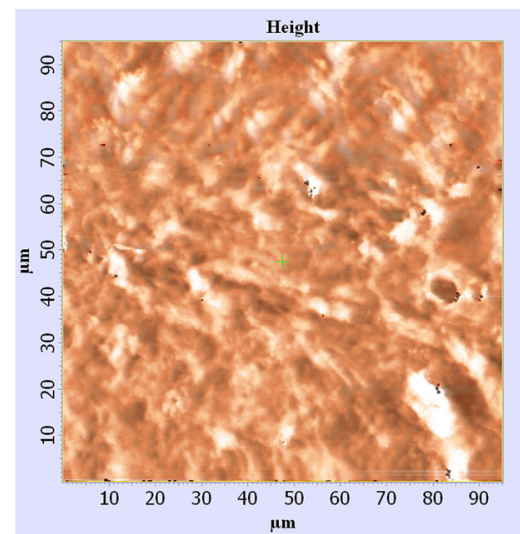

(f)

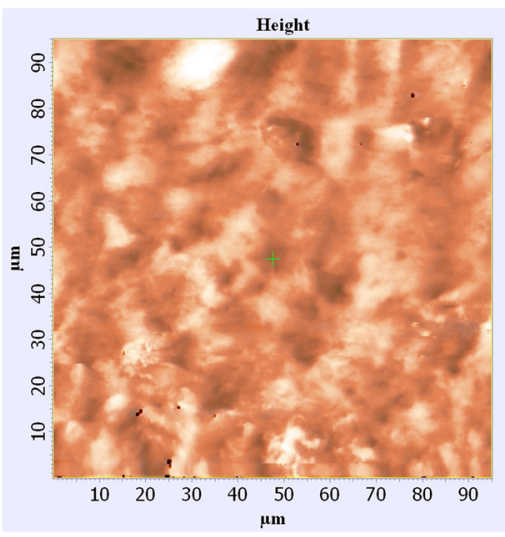

(i)
Fig. 2 Images of Atlantic salmon lateral ethmoid bone: a AFM image, b MFM image, c combined AFM and MFM images; images of northern pike lateral ethmoid bone: d AFM image, e MFM image,

they indicate the need to search for other functions of BMNs, not related to the magnetoreception. Therefore, this confirms the idea that BMNs have common metabolic functions not associated with magnetoreception in the overwhelming majority of organs and tissues of f combined AFM and MFM images; images of silver carp lateral ethmoid bone: $\mathbf{g}$ AFM image, $\mathbf{h}$ MFM image, $\mathbf{i}$ combined AFM and MFM images

animals (brain, heart, liver, lungs, intestines, muscles, skin, ethmoid bone), and in particular in organs and tissues of migratory and non-migratory fishes (brain, heart, liver, gills, intestines, muscles, skin, ethmoid bone, lateral ethmoid bone). 


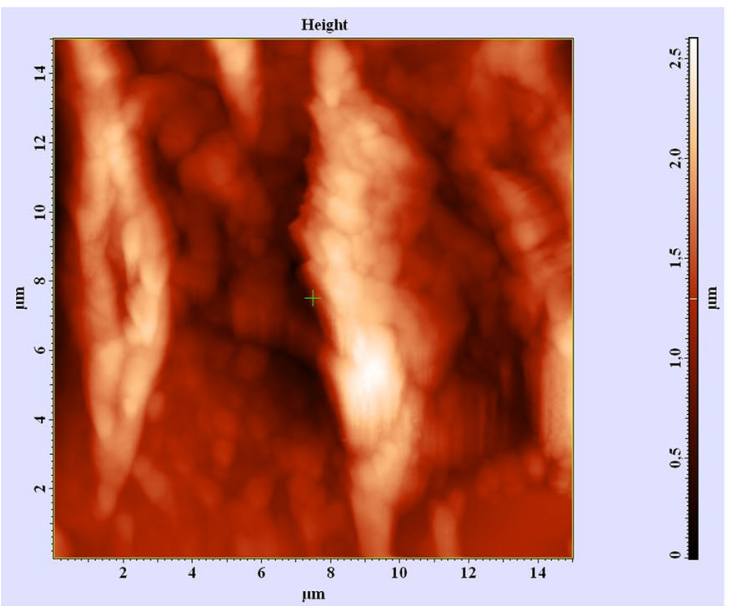

(a)

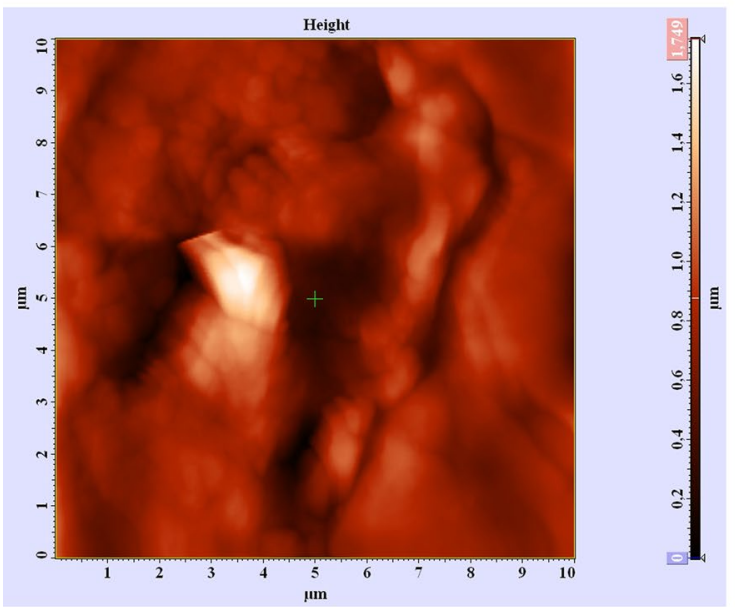

(c)

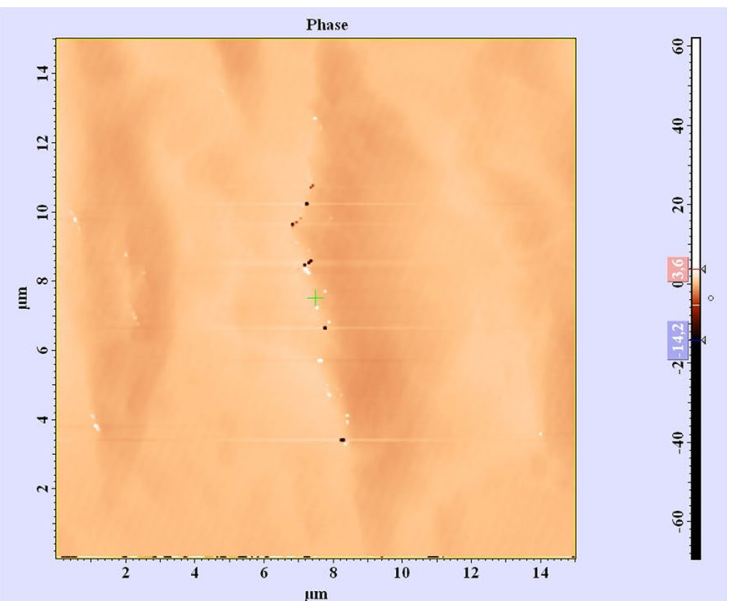

(b)

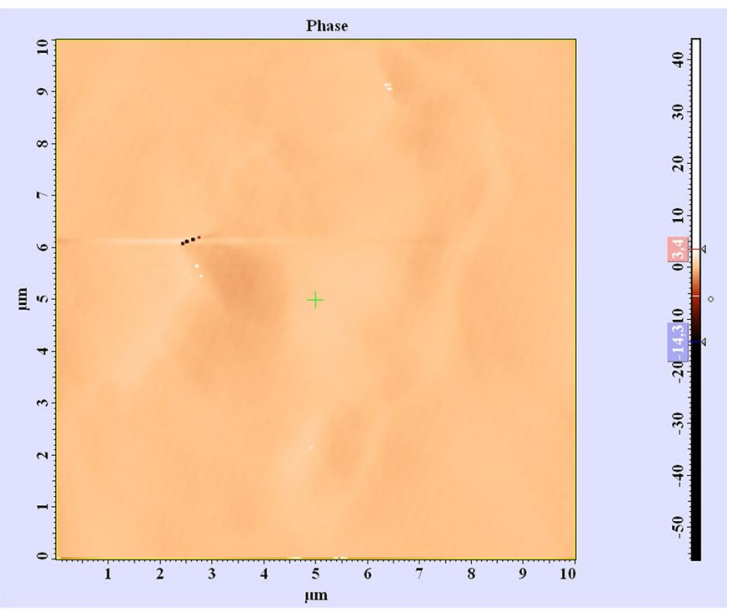

(d)

Fig. 3 Images of Atlantic salmon ethmoid bone $(15 \times 15 \mu \mathrm{m}$ section): a AFM image, b MFM image; images of northern pike ethmoid bone (10×10 $\mu$ m section): c AFM image, d MFM image

Table 4 The quantity of BMNs in the ethmoid and lateral ethmoid bones of migratory and non-migratory fishes

\begin{tabular}{lll}
\hline Migratory and non-migratory fishes & Fish organ & $\begin{array}{l}\text { Number of particles } \\
\text { (particles per } 100 \\
\text { microns }{ }^{2} \text { ) }\end{array}$ \\
\hline Atlantic salmon, Salmo salar & Ethmoid bone & $150 \pm 19$ \\
Northern pike, Esox lucius & Lateral ethmoid bone & $99 \pm 37$ \\
& Ethmoid bone & $57 \pm 3$ \\
Silver carp, Hypophthalmichthys molitrix & Lateral ethmoid bone & $72 \pm 17$ \\
& Ethmoid bone & $86 \pm 16$ \\
& Lateral ethmoid bone & $105 \pm 34$ \\
\hline
\end{tabular}


Acknowledgements This project has received funding from the European Union's Horizon 2020 research and innovation program under the Marie Skłodowska-Curie Grant Agreement No. 644348 (MagIC).

\section{References}

1. de Barros HG, Esquivel DM, Danon J, de Oliveira LP (1982) Magnetotactic algae. An Acad Bras Cienc 54:257-258

2. Cranfield CG, Dawe A, Karloukovski V, Dunin-Borkowski RE, de Pomerai D, Dobson J (2004) Biogenic magnetite in the nematode Caenorhabditis elegans. Proc Biol Sci 271:436-439. https:// doi.org/10.1098/rsbl.2004.0209

3. Lowenstam HA (1973) Magnetite in denticle capping in recent chitons. Geol Soc 11 Am Bull 73:435-438

4. Suzuki Y, Kopp RE, Kogure T et al (2006) Sclerite formation in the hydrothermal-vent "scaly-foot" gastropod: possible control of iron sulfide biomineralization by the animal. Earth Planet Sci Lett 242:39-50. https://doi.org/10.1016/j. epsl.2005.11.029

5. de Oliveira JF, Wajnberg E, Esquivel DM, Weinkauf S, Winklhofer M, Hanzlik M (2010) Ant antennae: are they sites for magnetoreception? J R Soc Interface 7:143-152. https://doi.org/10.1098/ rsif.2009.0102

6. Acosta-Avalos D, Wajnberg E, Oliveira PS, Leal I, Farina $M$, Esquivel DM (1999) Isolation of magnetic nanoparticles from Pachycondyla marginata ants. J Exp Biol 202:2687-2692

7. Gould JL, Kirschvink JL, Deffeyes KS (1978) Bees have magnetic remanence. Science 202:1026-1028. https://doi.org/10.1126/ science.201.4360.1026

8. Hsu CY, Ko FY, Li CW, Fann K, Lue JT (2007) Magnetoreception system in honeybees (Apis mellifera). PLoS ONE 4:e395. https ://doi.org/10.1371/journal.pone.0000395

9. Maher BA (1988) Magnetite biomineralization in termites. P R Soc Lond 265:733-737. https://doi.org/10.1098/ rspb.1998.0354

10. Lohmann KJ (1984) Magnetic remanence in the western Atlantic spiny lobster, Panulirus argus. J Exp Biol 113:29-41

11. Brassart J, Kirschvink JL, Phillips JB, Borland SC (1999) Ferromagnetic material in the eastern red-spotted newt Notophthalmus viridescens. J Exp Biol 202:3155-3160

12. Mann S, Sparks NH, Walker MM, Kirschvink JL (1988) Ultrastructure, morphology and organization of biogenic magnetite from sockeye salmon, Oncorhynchus nerka: implications for magnetoreception. J Exp Biol 140:35-49

13. Kirschvink JL (1989) Magnetite biomineralization and geomagnetic sensitivity in higher animals: an update and recommendations for future study. Bioelectromagnetics 10:239-259

14. Diebel CE, Proksch R, Greenk CR, Walker PN, Walker MM (2000) Magnetite defines a vertebrate magnetoreceptor. Nature 406:299-302. https://doi.org/10.1038/35018561

15. Gorobets S, Gorobets O, Bulaievska M, Sharau I (2018) Magnetic force microscopy of the ethmoid bones of migratory and non-migratory fishes. Acta Phys Pol A 133:734-737. https:// doi.org/10.12693/APhysPolA.133.734

16. Walcott C, Gould JL, Kirschvink JL (1979) Pigeons have magnets. Science 205:1027-1029. https://doi.org/10.1126/scien ce. 472725

17. Irwin WP, Lohmann KJ (2005) Disruption of magnetic orientation in hatchling loggerhead sea turtles by pulsed magnetic fields. J Comp Physiol A Neuroethol Sens Neural Behav Physiol 191:475-480. https://doi.org/10.1007/s00359-005-0609-9

18. Falkenberg G, Fleissner G, Schuchardt K et al (2010) Avian magnetoreception: elaborate iron mineral containing dendrites in the upper beak seem to be a common feature of birds. PLoS ONE 5:e9231. https://doi.org/10.1371/journ al.pone.0009231

19. Cadiou H, McNaughton PA (2010) Avian magnetite-based magnetoreception: a physiologist's perspective. J R Soc Interface 7:S193-S205. https://doi.org/10.1098/rsif.2009.0423.focus

20. Edwards HH, Schnell GD, DuBois RL, Hutchison VH (1992) Natural and induced remanent magnetism in birds. Auk 109:43-56

21. Edelman NB, Fritz T, Nimp S et al (2015) No evidence for intracellular magnetite in putative vertebrate magnetoreceptors identified by magnetic screening. Proc Natl Acad Sci USA 112:262267. https://doi.org/10.1073/pnas.1407915112

22. Holland R, Kirschvink J, Doak T, Wikelski M (2008) Bats use magnetite to detect the earth's magnetic field. PLoS ONE 3:e1676. https://doi.org/10.1371/journal.pone.0001676

23. Zoeger J, Dunn JR, Fuller M (1981) Magnetic material in the head of the common Pacific dolphin. Science 213(4510):892-894. https://doi.org/10.1126/science.7256282

24. Gorobets S, Medviediev O, Gorobets O, Ivanchenko A (2018) Biogenic magnetic nanoparticles in human organs and tissues. Prog Biophys Mol Biol 2:1. https://doi.org/10.1016/j.pbiomolbio .2018 .01 .010

25. Brem $F$, Hirt AM, Winklhofer $M$ et al (2006) Magnetic iron compounds in the human brain: a comparison of tumor and hippocampal tissue. J R Soc Interface 3:833-841. https://doi. org/10.1098/rsif.2006.0133

26. Fukumori Y, Oyanagi $H$, Yoshimatsu K (1997) Enzymatic iron oxidation and reduction in magnetite synthesizing Magnetospirillum magnetotacticum. J Phys IV Fr 7:659-662

27. Quintana C, Cowley JM, Marhic C (2004) Electron nanodiffraction and high-resolution electron microscopy studies of the structure and composition of physiological and pathological ferritin. J Struct Biol 147:166-178. https://doi.org/10.1016/j. jsb.2004.03.001

28. Collingwood J, Chong RK, Kasama T et al (2008) Three-dimensional tomographic imaging and characterization of iron compounds within Alzheimer's plaque core material. J Alzheimers Dis 14:235-245. https://doi.org/10.3233/JAD-2008-14211

29. Grassi-Schultheiss PP, Heller F, Dobson J (1997) Analysis of magnetic material in the human heart. Spleen Liver BioMet 10:351-355. https://doi.org/10.1023/A:1018340920329

30. Gorobets O, Gorobets S, Gorobets Y (2014) Biogenic magnetic nanoparticles: biomineralization in prokaryotes and eukaryotes. In: Lyshevski SE (ed) Dekker encyclopedia of nanoscience and nanotechnology, 3rd edn. CRC Press, New York, pp 300-308

31. Ullrich S, Kube M, Schübbe S, Reinhardt R, Schüler D (2005) A hypervariable 130-kilobase genomic region of Magnetospirillum gryphiswaldense comprises a magnetosome island which undergoes frequent rearrangements during stationary growth. J Bacteriol 187:7176-7184. https://doi.org/10.1128/ JB.187.21.7176-7184.2005

32. Schubbe S, Wurdemann Ch, Peplies J, Heyen U, Wawer $C$, Glockner F, Schuler D (2006) Transcriptional organization and regulation of magnetosome operons in Magnetospirillum gryphiswaldense. Appl Environ Microbiol 72:5757-5765. https://doi. org/10.1128/AEM.00201-06

33. Li W, Pio F, Pawłowski K, Godzik A (2000) Saturated BLAST: an automated multiple intermediate sequence search used to detect distant homology. Bioinformatics 16:1105-1110. https ://doi.org/10.1093/bioinformatics/16.12.1105

34. Kirschvink JL, Kobayashi-Kirschvink A, Woodford BJ (1992) Magnetite biomineralization in the human brain. Proc Natl Acad Sci 89:7683-7687. https://doi.org/10.1073/pnas.89.16.7683

35. Kobayashi A, Yamamoto N, Kirschvink J (1997) Studies of inorganic crystals in biological tissue: magnetite in human tumor. J Jpn Soc Powder Powder Metall 44:294-300 
36. Walker MM, Kirschvink JL, Dizon AE (1985) Chapter magnetite biomineralization and magnetoreception in organisms. 5:417437. https://doi.org/10.1007/978-1-4613-0313-8_20

37. Baker RR, Mather JG, Kennaugh JH (1983) Magnetic bones in human sinuses. Nature 303(6):78-80

38. Walker MM, Kirschvink JL, Chang S-BR, Dizon AE (1984) A candidate magnetic sense organ in the yellowfin tuna, Thunnus albacares. Science 224:751-753. https://doi.org/10.1126/scien ce.224.4650.751

39. Walker MM, Quinn TP, Kirschvink JL, Groot T (1988) Production of single-domain magnetite throughout life by sockeye salmon, Oncorhynchus nerka. J Exp Biol 140:51-63

40. Moore A, Freake SM, Thomas IM (1990) Magnetic particles in the lateral line of the Atlantic salmon (Salmo salar L.). Philos Trans R Soc Lond B Biol Sci 329:11-15. https://doi.org/10.1098/ rstb.1990.0145

41. Richter M, Kube M, Bazylinski D, Lombardot T, Glöckner FO, Reinhardt R et al (2007) Comparative genome analysis of four magnetotactic bacteria reveals a complex set of group-specific genes implicated in magnetosome biomineralization and function. J Bacteriol 189:4899-4910. https://doi.org/10.1128/ JB.00119-07

42. Lohße A, Ullrich S, Katzmann E et al (2011) Functional analysis of the mag-netosome island in Magnetospirillum gryphiswaldense: the mamAB operon is sufficient for magnetite biomineralization. PLoS ONE 6:e25561. https://doi.org/10.1371/journal.pone.0025561

43. Schübbe $S$, Williams TJ, Xie G, Kiss HE, Brettin TS, Martinez D, Ross CA, Schüler D, Cox BL, Nealson KH, Bazylinski DA (2009) Complete genome sequence of the chemolithoautotrophic marine magnetotactic coccus strain MC-1. Appl Environ Microbiol 75:4835-4852. https://doi.org/10.1128/AEM.02874-08

44. Komeili A, Li Z, Newman DK, Jensen GJ (2006) Magnetosomes are cell membrane invaginations organized by the action-like protein MamK. Science 311:242-245. https://doi.org/10.1126/ science.1123231

45. Palmiter RD, Huang $L$ (2004) Efflux and compartmentalization of zinc by members of the SLC30 family of solute carriers. Pflugers Arch Eur J Physiol 447:744-751. https://doi.org/10.1007/s0042 4-003-1070-7

46. Jeong J, Eide DJ (2013) The SLC39 family of zinc transporters. Mol Aspects Med 34:612-619. https://doi.org/10.1016/j. mam.2012.05.011

47. Zumbrunn J, Trueb B (1996) Primary structure of a putative serine protease specific for IGF-binding proteins. FEBS Lett 398:187-192

48. Schädler S, Burkhardt C, Hegler F, Straub KL, Miot J, Benzerara K, Kappler A (2009) Formation of cell-iron-mineral aggregates by phototrophic and nitrate-reducing anaerobic Fe(II)oxidizing bacteria. Geomicrobiol J 26:93-103. https://doi. org/10.1080/01490450802660573

49. Ritz T, Thalau P, Phillips JB, Wiltschko R, Wiltschko W (2004) Resonance effects indicate radical pair mechanism for avian magnetic compass. Nature 429:177-180. https://doi.org/10.1038/ nature 02534 